Clinical Endocrinology (1988), 28, 647-656

\title{
EFFECTS OF CHANGING GONADOTROPHIN-RELEASING HORMONE PULSE FREQUENCY ON GONADOTROPHIN SECRETION IN MEN
}

\author{
S. E. SAUDER, M. S. FRAGER, G. D. CASE, R. P. KELCH \\ AND J. C. MARSHALL
}

Divisions of Endocrinology and Metabolism, Departments of Pediatrics and Internal Medicine, and the Reproductive Endocrinology Program, University of Michigan, Ann Arbor, Michigan 48109 and the Department of Pediatrics, University of Illinois College of Medicine at Peoria, Peoria, Illinois 61656, USA

(Received 21 September 1987; returned for revision 1 December 1987; finally revised 19 January 1988; accepted 3 February 1988)

\section{SUMMARY}

To investigate the effects of alterations in GnRH pulse frequency on gonadotrophin secretion, we administered low dose $\mathrm{GnRH}$ pulses $(25 \mathrm{ng} / \mathrm{kg})$ at hourly or 2-hourly frequencies to eight normal men. All subjects received GnRH pulses i.v. every $2 \mathrm{~h}$ for $88 \mathrm{~h}$. Following this, exogenous $\mathrm{GnRH}$ was discontinued in four normal men (Group A, GnRH withdrawal), and the frequency of GnRH injections was increased to one pulse every hour for $24 \mathrm{~h}$ in the other four normal men (Group B, hourly GnRH). Blood samples were obtained every $20 \mathrm{~min}$ for LH and FSH and every $12 \mathrm{~h}$ for testosterone $(\mathrm{T})$ and oestradiol $\left(\mathrm{E}_{2}\right)$. Plasma $\mathrm{LH}$ increased in all subjects during injection of $\mathrm{GnRH}$ pulses every $2 \mathrm{~h}$. Withdrawal of GnRH pulses in Group A men was accompanied by a fall in mean $L H$, reductions in $\mathrm{LH}$ pulse amplitude $(\bar{x} \pm$ SEM: control $6.5 \pm 1.0$; $\mathrm{GnRH}$ withdrawal $4.0 \pm 0.5 \mathrm{mIU} / \mathrm{ml}$ ) and pulse frequency (control $5.5 \pm 0.2 ; \mathrm{GnRH}$ withdrawal $3.5 \pm 0.7$ pulses $/ 12 \mathrm{~h}$ ), and an increase in plasma $E_{2}$ (control $122 \pm 15$; GnRH withdrawal $340 \pm 37 \mathrm{pmol} / \mathrm{l}$ ). Gonadotrophin responses to GnRH $(25 \mathrm{ng} / \mathrm{kg})$ were normal when tested $32 \mathrm{~h}$ after $\mathrm{GnRH}$ withdrawal. Injection of hourly GnRH pulses in Group B men was accompanied by a timedependent change in mean LH, which transiently rose, then fell, and subsequently rose to a plateau during the second $12 \mathrm{~h}$ period of hourly GnRH. The final rise in LH was accompanied by an increase in LH frequency to $11 \cdot 8 \pm 0.3$ pulses $/ 12 \mathrm{~h}$. These data suggest that: (1) increases in gonadal steroids decrease LH secretion by reducing the amplitude and frequency of endogenous $\mathrm{GnRH}$ pulses; and (2) the normal adult male pituitary requires approximately $12 \mathrm{~h}$ to initiate a sustained increase in $\mathrm{LH}$ secretion in response to a doubling in $\mathrm{GnRH}$ pulse frequency.

Correspondence: Dr Sue Ellyn Sauder, Department of Pediatrics, University of Illinois College of Medicine at Peoria Peoria, IL 61656, USA. 
Previous studies have shown that the frequency of LH pulses changes during human sexual maturation and the menstrual cycle. Studies in early pubertal children have suggested that LH pulse frequency and amplitude increase transiently during sleep (Corley et al., 1981; Kelch et al., 1985; 1987). During the menstrual cycle, LH pulse frequency increases significantly between the early and late stages of the follicular phase and slows to one pulse every $90-360 \mathrm{~min}$ in the luteal phase (Santen \& Bardin, 1973; Backstrom et al., 1982; Reame et al., 1984; Filicori et al., 1986). Studies in animals have also shown changes in the periodicity of pulsatile gonadotrophin secretion. Immediately before the $\mathrm{LH}$ peak in ewes, $\mathrm{LH}$ pulse frequency increases markedly and pulse amplitude is reduced (Goodman \& Karsch, 1981). In rats, LH pulse frequency increases during the second day of the oestrous cycle (Gallo, 1981).

Changes in the frequency of pulsatile LH secretion most likely represent alterations in GnRH pulse frequency. Carmel et al. (1976) have shown that GnRH is secreted by the hypothalamus in an episodic manner in monkeys, and studies in sheep (Clarke \& Cummins, 1982) have documented that each LH pulse in peripheral venous blood is associated with a GnRH pulse in hypophyseal portal blood.

These observations have led to the hypothesis that alterations in GnRH pulse frequency may be important in the regulation of gonadotrophin secretion. Indeed, data from studies in rats support this hypothesis by showing that the number of pituitary GnRH receptors and acute LH release are modulated by changes in GnRH pulse frequency (Katt et al., 1985). In the present study, we administered low dose pulses of synthetic GnRH i.v. at hourly or 2-hourly frequencies to normal men and evaluated the effects on LH, FSH, testosterone, and oestradiol secretion. The dose of GnRH pulses was chosen to mimic physiological secretion of $\mathrm{GnRH}$.

\section{MATERIALS AND METHODS}

\section{Subjects}

Eight normal adult male volunteers, aged 19-27 years, were randomly assigned to study group A or B. All had experienced normal growth and maturation by history and had normal adult male sexual development; no subject was receiving medications.

\section{Study protocol}

The studies were approved by the Human Investigation Committee of the University of Michigan and were performed after written informed consent had been obtained.

Subjects were admitted to the Clinical Research Center on the day before blood sampling to permit acclimatization to the unit where they were allowed to walk about throughout the study. On admission, an indwelling i.v. cannula was placed in a forearm vein for blood withdrawal and injection of saline or GnRH pulses. On the day after admission (day O), pulses of normal saline $(2 \mathrm{ml})$ were injected i.v. every $2 \mathrm{~h}$ for $24 \mathrm{~h}$ to serve as a control for subsequent GnRH injections. Beginning at $0800 \mathrm{~h}$ on day 1, all subjects received low dose pulses of synthetic $\mathrm{GnRH}(25 \mathrm{ng} / \mathrm{kg})$ which were administered every $2 \mathrm{~h}$ by rapid i.v. bolus injection; this was continued for $88 \mathrm{~h}$ until $2400 \mathrm{~h}$ on day 4 . Thereafter, subjects entered into one of two study designs: GnRH withdrawal or hourly GnRH. 


\section{Group A: GnRH withdrawal}

Four normal men in this group received i.v. pulses of saline every $2 \mathrm{~h}$ from $0200-2400 \mathrm{~h}$ on day 5 , and a single low dose pulse of $\mathrm{GnRH}(25 \mathrm{ng} / \mathrm{kg})$ was injected at $0800 \mathrm{~h}$ on day 6 .

\section{Group B: hourly GnRH}

The four normal men in group B received i.v. pulses of GnRH ( $25 \mathrm{ng} / \mathrm{kg})$ every $1 \mathrm{~h}$ from $0100 \mathrm{~h}$ on day 5 until $0100 \mathrm{~h}$ on day 6 and a single pulse of $\mathrm{GnRH}(25 \mathrm{ng} / \mathrm{kg})$ at $0800 \mathrm{~h}$ on day 6.

In all subjects, plasma LH and FSH were determined from blood samples obtained every $20 \mathrm{~min}$ from $0800 \mathrm{~h}$ (day 0) to $0740 \mathrm{~h}$ (day 1) and again from $1200 \mathrm{~h}$ (day 4) to $0200 \mathrm{~h}$ (day 6). Plasma LH and FSH were also measured at $0800 \mathrm{~h}, 0820 \mathrm{~h}$, and $0840 \mathrm{~h}$ on days $1-4$ and day 6 and at hourly intervals from $0200-0800 \mathrm{~h}$ on day 6 . Plasma testosterone and oestradiol concentrations were determined each day at $0800 \mathrm{~h}$ and $2000 \mathrm{~h}$.

\section{GnRH dosage}

The dosage of i.v. synthetic GnRH used in this study $(25 \mathrm{ng} / \mathrm{kg})$ was based on earlier estimates that pituitary portal plasma concentrations of $\mathrm{GnRH}$ in men vary between 30-300 pg/ml (Kelch et al., 1975; Huseman \& Kelch, 1978). After administration of this GnRH dosage to normal men, peripheral plasma GnRH concentrations average $299 \pm 70 \mathrm{pg} / \mathrm{ml}$ (Valk et al., 1981). Moreover, increments in plasma LH after i.v. injection of $25 \mathrm{ng} / \mathrm{kg} \mathrm{GnRH}$ in early pubertal boys closely approximate spontaneous nocturnal LH pulses in these children (Corley et al., 1981), and administration of this dose of GnRH to normal men elicits LH responses similar to endogenous LH pulses (Valk et al., 1981).

\section{Assays and analysis of results}

Plasma LH, FSH, testosterone, and oestradiol were measured by RIA (Midgley, 1966; 1967; Ismail et al., 1972; England et al., 1974). Gonadotrophin concentrations are reported as milli international units of the Second International Reference Preparation of human menopausal gonadotrophin urinary standard after conversion from First International Reference Preparation of pituitary FSH/LH (Medical Research Council 69/104), which was used as the assay standard. For plasma LH concentrations of 2.5, 7.5, and $15 \mathrm{mIU} / \mathrm{ml}$, the intra-assay coefficients of variation (CV) averaged $20 \%, 9.5 \%$ and $6.6 \%$, respectively. The inter-assay CV was $11 \%$ for the LH and FSH assays and approximately $15 \%$ for the steroid assays. Samples from each subject were analyzed in two consecutive gonadotrophin assays and in one steroid assay. Téstosterone concentrations are expressed as $\mathrm{nmol} / 1(1 \mathrm{ng} / \mathrm{ml}$ testosterone $=3.5 \mathrm{nmol} / \mathrm{l})$. Oestradiol concentrations are expressed as pmol $/ 1(1 \mathrm{pg} / \mathrm{ml}$ oestradiol $=3.7 \mathrm{pmol} / \mathrm{l})$.

Mean gonadotrophin concentrations were determined by calculating the arithmetic means of LH and FSH values obtained at 20 min intervals during $4 \mathrm{~h}$ periods. A significant LH pulse was defined as a rise from nadir to peak within 40 min that was equal to or greater than a mean detectable increment (MDI) which was determined by twice the intra-assay coefficient of variation of replicate samples from each subject (MDI = mean LH concentration $\times \mathrm{CV} \times 2$ ). The rationale for this method and comparison with other computerized methods have been reported previously (Reame et al., 1984). 


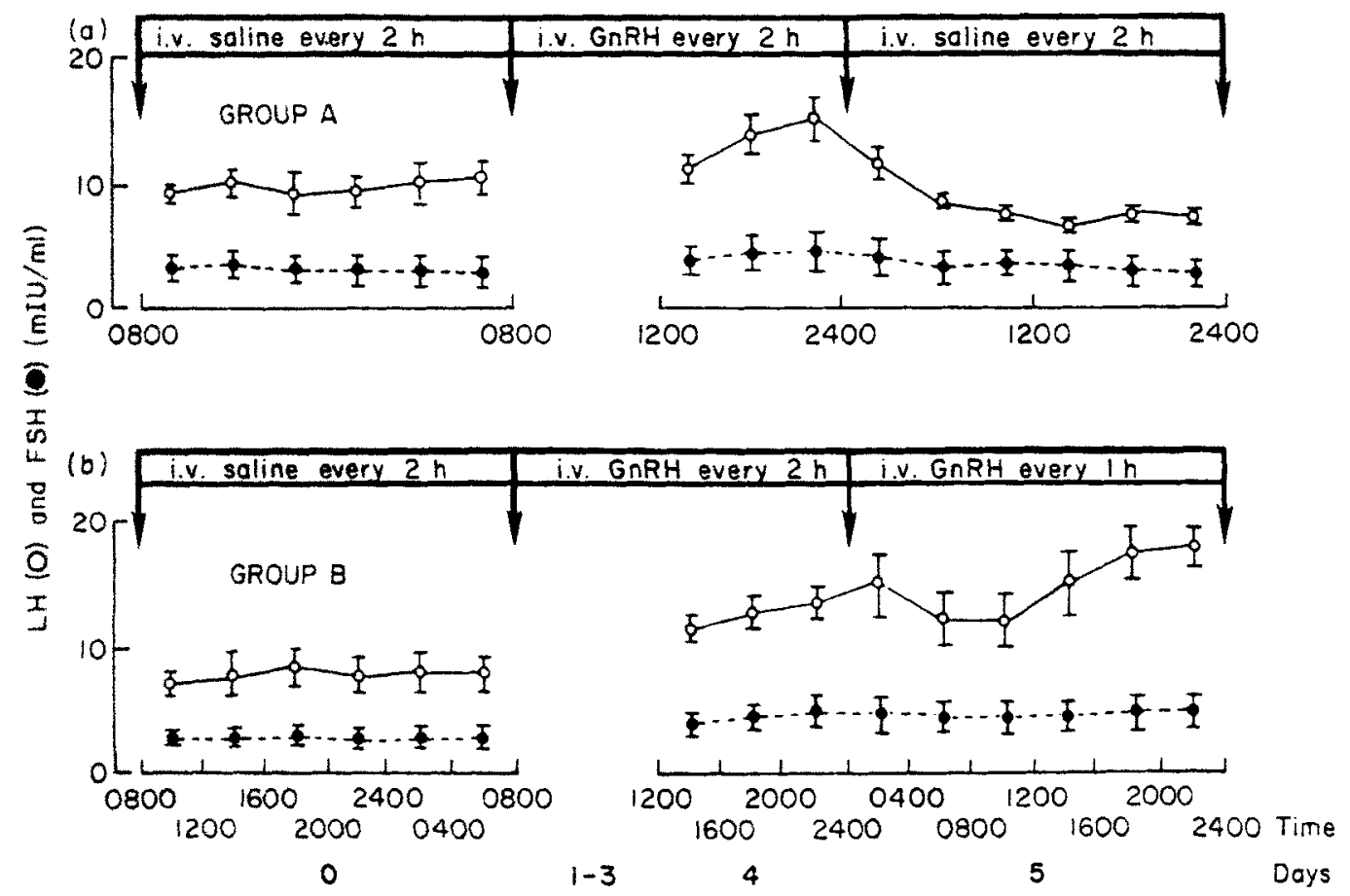

Fig. 1. Mean \pm SEM plasma $L H(0)$ and FSH $(0)$ concentrations during 4 h periods in normal men: (a) Group A, GnRH withdrawal $(n=4)$; (b) Group B, hourly GnRH $(n=4)$.

Within each group of normal men, comparisons of gonadotrophin and gonadal steroid concentrations before, during and after pulsatile $\mathrm{GnRH}$ administration were performed by analysis of variance for repeated measures, followed by the Newman-Keuls' post-hoc comparison test (Bruning \& Kintz, 1977). In addition, the Chi-Square (Goodness of Fit) test was used to compare the patterns of change in mean LH on days 0 and 5 (Hopkins \& Glass, 1978). Results are expressed as mean \pm SEM.

\section{RESULTS}

\section{Group A (normal men; GnRH withdrawal)}

Administration of $\mathrm{GnRH}$ pulses every $2 \mathrm{~h}$ resulted in a significant increase in the mean $\mathrm{LH}$ concentration at the end of day $4(2000-2340 \mathrm{~h})$ compared to that on day $0(P<0.01$; Fig. 1). Withdrawal of GnRH pulses was accompanied by a significant fall in mean LH on day 5 compared to day $4(P<0.01)$, and values were similar to or below (day $5,1200-1540$ h; $P<0.05$ ) those measured during day 0 (Fig. 1). Spontaneous LH pulse amplitude and frequency were decreased significantly on day 5 compared to those on days 0 and 4 $(P<0.05$, Table 1). LH responses to $\mathrm{GnRH}$ at $0800 \mathrm{~h}$ on day 6 were comparable to those measured at $0800 \mathrm{~h}$ on days 1,2 , and 4 and greater than $(P<0.05)$ those on day 3 (data not shown). 
Table 1. Effects of exogenous GnRH pulses on LH pulses in normal men: (A) GnRH withdrawal; (B) hourly GnRH (mean \pm SEM)

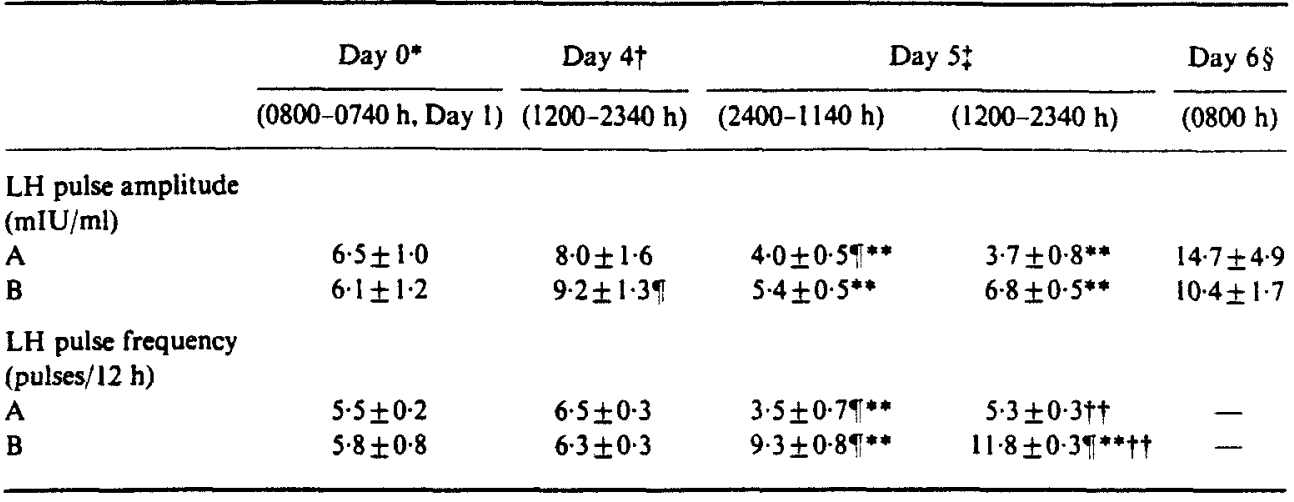

* Saline every 2 h i.v.

+ GnRH every 2 h i.v.

† Saline every 2 h i.v. - Group A; GnRH every 1 h i.v. - Group B.

$\S \mathrm{GnRH}$ at $0800 \mathrm{~h}$ i.v.

If $P<0.05$ us Day 0

* $P<0.05$ us Day $4(1200-2340 \mathrm{~h})$.

$++P<0.05$ us Day $5(2400-1140 \mathrm{~h})$.

Figure 2 illustrates pulsatile gonadotrophin secretion in one subject from group A. Note that $\mathrm{LH}$ responses to $\mathrm{GnRH}$ on day $4(10.7 \pm 0.8 \mathrm{mIU} / \mathrm{ml})$ were similar in magnitude to amplitudes of endogenous $\mathrm{LH}$ pulses on day $0(9.1 \pm 1.1 \mathrm{mIU} / \mathrm{ml})$. The decline in $\mathrm{LH}$ secretion during GnRH withdrawal was associated with a reduction in endogenous $\mathrm{LH}$ pulse amplitude on day $5(5.3 \pm 0.8 \mathrm{mIU} / \mathrm{ml})$.

Plasma oestradiol concentrations rose significantly in group A subjects on day 5 following pulsatile $\mathrm{GnRH}$ administration $(P<0.05$, Table 2$)$. Although mean plasma testosterone values appeared to increase during and after exogenous $\mathrm{GnRH}$ pulses, differences were not significant when compared to values on day 0 (Table 2).

\section{Group B (normal men; hourly GnRH)}

As in group A, administration of GnRH pulses every $2 \mathrm{~h}$ to group B subjects resulted in increased mean LH concentrations on day $4(2000-2340 \mathrm{~h})$ compared to those on day 0 $(P<0.01$; Fig. 1$)$; this was associated with an augmentation in $\mathrm{LH}$ pulse amplitude $(P<0.05$, Table 1$)$. The increase in the frequency of $\mathrm{GnRH}$ injections to one pulse every hour was accompanied by a time-dependent pattern of change in mean plasma LH during day 5 which was significantly different from that during day $0(P<0.001 ;$ Fig. 1$)$. Mean LH concentrations rose transiently and then fell during the first $12 \mathrm{~h}$ of hourly $\mathrm{GnRH}$ (day 5, 2400-1140 h). Subsequently, plasma $\mathrm{LH}$ values rose to a plateau during the second $12 \mathrm{~h}$ period of hourly GnRH on day 5 and were higher than values on days 0 and 4 $(P<0.01)$. During the initial fall in mean LH (day $5,2400-1140 \mathrm{~h}), \mathrm{LH}$ pulse amplitude was reduced compared to day $4(P<0.05$, Table 1$)$, and $\mathrm{LH}$ responses were detected after only 37 of $48 \mathrm{GnRH}$ pulses. The subsequent rise in plasma LH (day 5, 1200-2340 h) was associated with an increase in LH pulse frequency $(P<0.05$, Table 1$)$; during the second 


\begin{tabular}{|c|c|c|c|c|c|}
\hline & & line every $2 \mathrm{~h}$ & i.v. GnRH every $2 \mathrm{~h}$ & i.v. soline every $2 \mathrm{~h}$ & $\mathrm{GnRH}$ \\
\hline (nmol/1) & $22 \cdot 4$ & 172 & 18.922 .133 .3301 & $25 \cdot 2$ & $27 \cdot 7$ \\
\hline$E_{2}(\mathrm{pmol} / 1)$ & 155 & - & $218 \quad 89 \quad 300 \quad 270$ & 300 & 296 \\
\hline
\end{tabular}

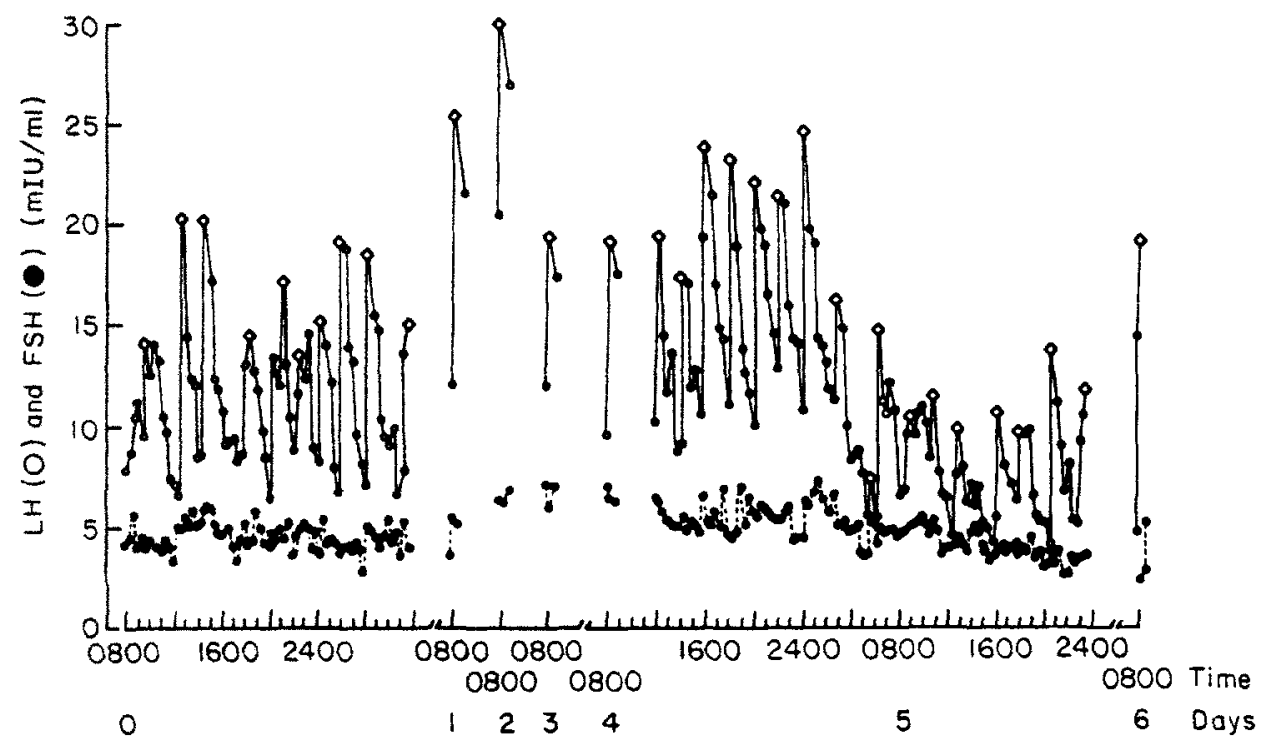

Fig. 2. Endogenous plasma LH $(0)$ and FSH (๑) secretory patterns (Days 0 and 5 ) and gonadotrophin responses to i.v. injections of low dose GnRH pulses every 2 h (days $1-4)$ in a normal male subject from Group A. (0) Significant LH pulses. Plasma testosterone (T) and oestradiol $\left(E_{2}\right)$ concentrations, obtained throughout the study, are shown at the top.

$12 \mathrm{~h}$ period of hourly GnRH injections, significant LH responses occurred after 47 of 48 GnRH pulses.

Data from one subject in group B (Fig. 3) illustrate the decline in plasma LH concentrations during the initial $12 \mathrm{~h}$ period of hourly $\mathrm{GnRH}$ pulses on day 5 . The fall in mean LH was accompanied by a reduction in $\mathrm{LH}$ pulse amplitude from $12 \cdot 6 \pm 2 \cdot 1 \mathrm{mIU} /$ $\mathrm{ml}$ on day $4(1200-2340 \mathrm{~h})$ to $6.3 \pm 1.0 \mathrm{mIU} / \mathrm{ml}$ on day $5(2400-1140 \mathrm{~h})$. Following this, plasma $\mathrm{LH}$ rose abruptly, accompanied by an increase in $\mathrm{LH}$ pulse frequency. Ten pulses were detectable during the initial $12 \mathrm{~h}$ of hourly GnRH injections, and 12 pulses were seen during the second $12 \mathrm{~h}$ period.

Plasma testosterone and oestradiol concentrations in group B subjects were increased significantly during GnRH injections $(P<0.05$; Table 2$)$.

\section{DISCUSSION}

Changes in the frequency of pulsatile LH secretion, and presumably GnRH secretion, have been clearly documented in previous studies in animals and humans. During the human female reproductive cycle, LH pulse frequency increases significantly between the early and late stages of the follicular phase (Goodman \& Karsch, 1981; Backstrom et al., 
Table 2. Effects of exogenous GnRH pulses on plasma gonadal steroid concentrations in normal men: (A) GnRH withdrawal; (B) hourly GnRH (mean \pm SEM)

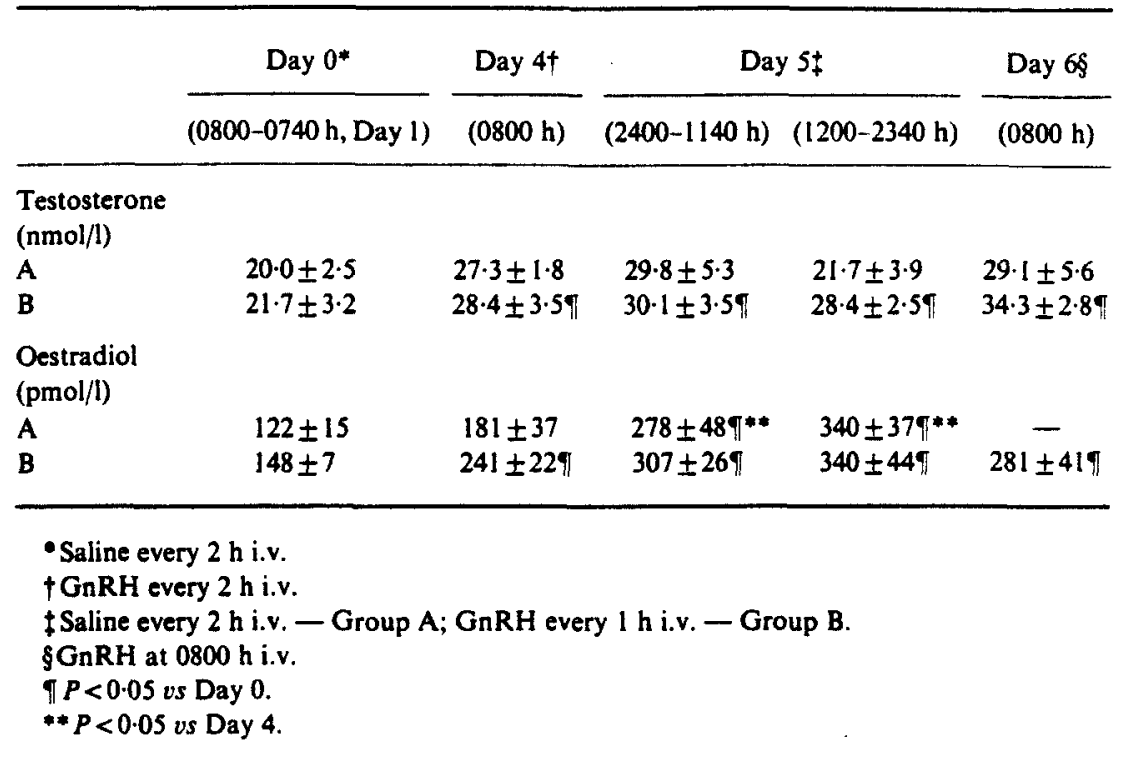

1982; Reame et al., 1984) and decreases significantly during the luteal phase (Santen \& Bardin, 1973; Hauger et al., 1977; Backstrom et al., 1982; Reame et al., 1984; Filicori et al., 1986). These data suggest that alterations in GnRH pulse frequency are important in the regulation of pulsatile gonadotrophin secretion. In support of this view, Wildt $e t$ al. (1981) have reported that, in ovariectomized rhesus monkeys with hypothalamic lesions which eliminated endogenous $\mathrm{GnRH}$ secretion, a reduction in the frequency of exogenous GnRH pulses from every hour to every $3 \mathrm{~h}$ resulted in a significant increase in plasma FSH and a decrease in plasma LH concentrations. Similarly, Gross et al. (1987) have demonstrated recently that, in men with isolated gonadotrophin deficiency and presumed endogenous GnRH deficiency, serum FSH concentrations increased progressively relative to LH concentrations as the frequency of exogenous $\mathrm{GnRH}$ pulses was decreased. The present study was designed to evaluate the effects of changing the frequency of exogenous $\mathrm{GnRH}$ pulses on pulsatile gonadotrophin secretion in normal men.

Injection of GnRH pulses every $2 \mathrm{~h}$ for $88 \mathrm{~h}$ resulted in increased plasma $\mathrm{LH}$ concentrations in all eight normal men. This was presumably due to increased pituitary exposure to $\mathrm{GnRH}$ from the additive effects of exogenous $\mathrm{GnRH}$ pulses and endogenous GnRH secretion. Pulsatile GnRH administration was also associated with increased plasma oestradiol concentrations, which rose to a greater degree than testosterone. These findings are consistent with results of GnRH infusions in normal men, in whom serum LH rose significantly and serum oestradiol was increased relative to testosterone during exogenous GnRH administration (McNeil et al., 1979).

Withdrawal of exogenous $\mathrm{GnRH}$ pulses resulted in a fall in mean plasma LH. This was accompanied by reductions in endogenous LH pulse amplitude and frequency. Factors responsible for the changes in pulsatile LH secretion during exogenous GnRH withdrawal cannot be determined with certainty from the present data. However, one 


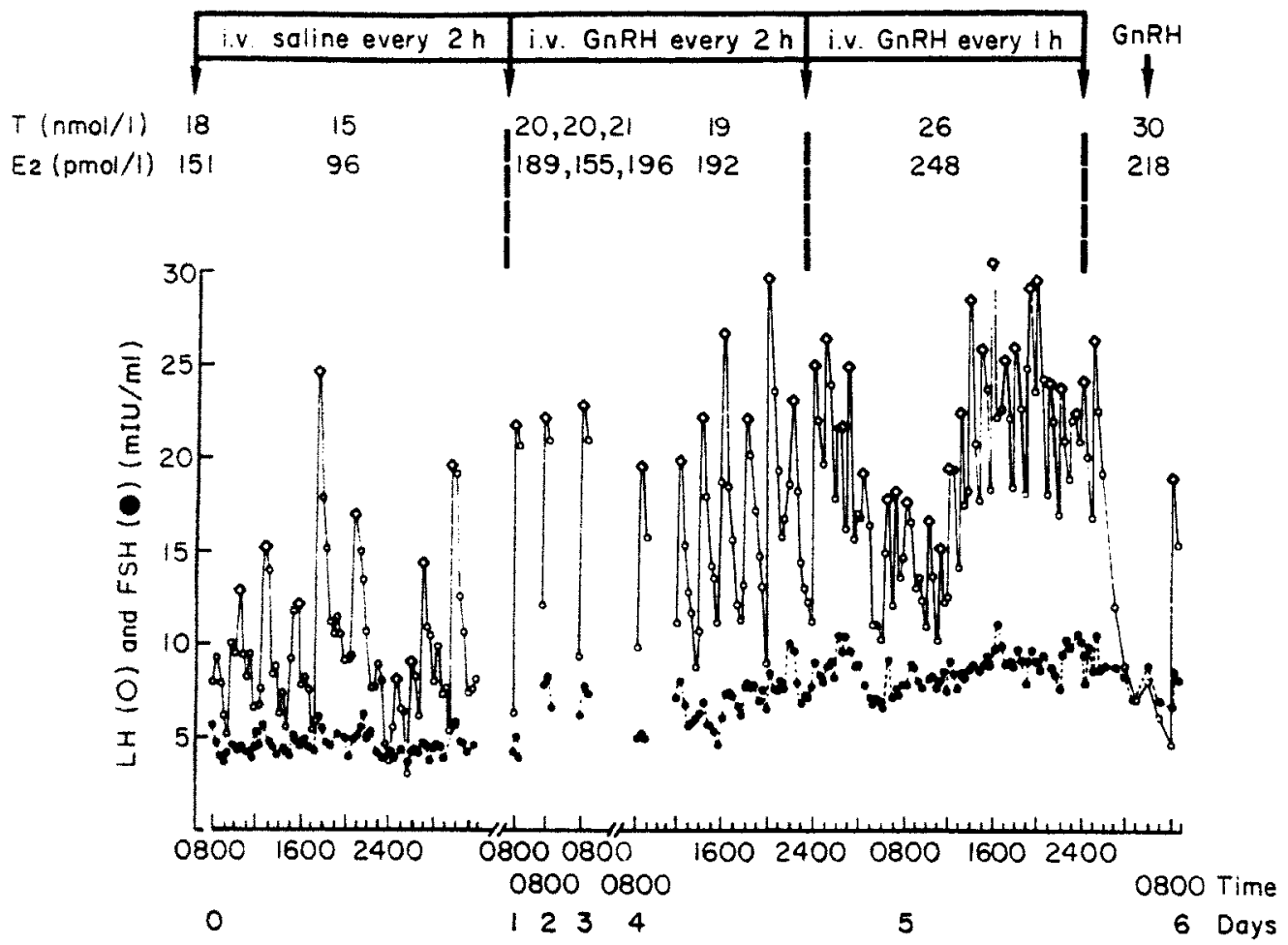

Fig. 3. Endogenous plasma LH (0) and FSH (๑) secretory patterns (day 0 ) and gonadotrophin responses to i.v. injections of low dose GnRH pulses every 2 h (days $1-4$ ) or every 1 h (day 5 ) in a normal male subject from Group B. ( $)$ Significant LH pulses. Plasma testosterone (T) and oestradiol $\left(E_{2}\right)$ concentrations are shown at the top.

possibility is that the observed changes were due to modulation of endogenous GnRH and/or gonadotrophin secretion by increased plasma concentrations of gonadal steroids. In support of this assumption, studies in normal men have shown that infusions of oestradiol decrease LH pulse amplitude and pituitary sensitivity to $\mathrm{GnRH}$ and infusions of testosterone decrease LH pulse frequency (Santen, 1975). Moreover, Matsumoto and Bremner (1984) have reported that endogenous LH pulse amplitude and frequency are significantly higher in men with primary hypogonadism than in normal men, and testosterone therapy is accompanied by significant reductions in both amplitude and frequency. In the present study, the decrease in LH pulse frequency during GnRH withdrawal was presumably due to a reduction in endogenous GnRH pulse frequency. The decrease in endogenous LH pulse amplitude on day 5 could have been due to reductions in endogenous GnRH pulse amplitude and/or decreased pituitary sensitivity to $\mathrm{GnRH}$; however, the demonstration of normal LH responsiveness to GnRH on day 6 in group A subjects makes the latter possibility less likely.

The acute increase in exogenous GnRH pulse frequency on day 5 in group B subjects was accompanied by a time-dependent pattern of change in LH secretion, characterized by a transient rise, a subsequent fall, and a final rise in mean LH. During the decline in mean LH, pulse amplitude was significantly reduced, and LH response, were not 
detectable after approximately one-fourth of the exogenous GnRH pulses. The final rise in $\mathrm{LH}$ was accompanied by an increase in $\mathrm{LH}$ pulse frequency; indeed, $\mathrm{LH}$ responses were identified following $98 \%$ of $\mathrm{GnRH}$ pulses administered during the latter half of day 5 . These data suggest that, in men with intact hypothalamic--pituitary-gonadal axes, it takes the pituitary gland approximately $12 \mathrm{~h}$ to become fully responsive to a doubling in GnRH pulse frequency. This temporal delay in pituitary responsiveness presumably represents the time required by the gonadotroph to alter its mode of LH synthesis and/or secretion subsequent to an acute increase in $\mathrm{GnRH}$ pulse frequency. However, in-vivo studies, such as the present one, do not allow for determination of the exact intracellular mechanism responsible for this adaptation. Although acute changes in endogenous LH pulse frequency have not been identified in normal men, several investigators have documented an increase in $\mathrm{LH}$, and presumably $\mathrm{GnRH}$, pulse frequency between the early and late stages of the follicular phase of the menstrual cycle in women (Backstrom $e t$ al., 1982; Reame et al., 1984; Filicori et al., 1986). During this phase of the cycle, a similar pattern of gonadotrophin secretion is seen immediately before the midcycle LH surge, namely a transient fall in mean LH (Midgley \& Jaffe, 1971) followed by an acute increase in mean LH and LH pulse amplitude (Reame et al., 1984).

\section{ACKNOWLEDGEMENTS}

We gratefully acknowledge the expert technical assistance of Mara Markovs, Regina Jakacki, Katherine Kersey, and Elsie Kolb, the excellent secretarial support of Susie Jobe and Debbie Batey, and the assistance of the nursing staff of the Clinical Research Center. We also thank Margie Tomsic and Jean Aldag, for their advice on statistical analysis. Synthetic LRF (GnRH) was supplied by Parke-Davis/Warner-Lambert Co. (Detroit, MI). This study was supported by NIH grants of RPK (USPHS HD 16000) and JCM (USPHS HD 11489) and the General Clinical Research Program Grant 5M01RR-42.

\section{REFERENCES}

BaCkstrom, C.T., MCNellly, A.S., LeAsK, R.M. \& Baird, D.T. (1982) Pulsatile secretion of LH, FSH, prolactin, oestradiol, and progesterone during the human menstrual cycle. Clinical Endocrinology 17, 29-42.

BRUNING, J.L. \& KINTZ, B.L. (1977) Computational Handbook of Statistics, 2nd edition. Scott, Foresman \& Co., Glenview, llinois.

Carmel, P.W., Araki, S. \& Ferin, M. (1976) Pituitary stalk portal blood collection in Rhesus monkeys: evidence for pulsatile release of gonadotropin-releasing hormone (GnRH). Endocrinology, 99, 243-248.

CLARKE, I.J. \& CUMmINS, J.T. (1982) The temporal relationship between gonadotropin-releasing hormone $(\mathrm{G} n \mathrm{RH})$ and luteinizing hormone (LH) secretion in overiectomized ewes. Endocrinology, 111, 1737-1739.

CORLEY, K.P., VALK, T.W., KeLCH, R.P. \& MARSHALL, J.C. (1981) Estimation of GnRH pulse amplitude during pubertal development. Pediatric Research, 15, 157-162.

England, B.G., Niswender, G.D. \& Midgley, JR., A.R. (1974) Radioimmunoassay of estradiol 17 beta without chromatography. Journal of Clinical Endocrinology and Metabolism, 38, 42-50.

FILICORI, M., SANTORO, N., MERRIAM, G.R. \& CROWLEY, JR., W.F. (1986) Characterization of the physiological pattern of episodic gonadotropin secretion throughout the human menstrual cycle. Journal of Clinical Endocrinology and Metabolism, 62, 1136-1144.

GaLLO, R.V. (1981) Pulsatile LH release during periods of low level LH secretion in the rat estrous cycle. Biology of Reproduction, 24, 771-777.

GOODMAN, R.L. \& KarSCH, F.J. (1981) The hypothalamic pulse generator: a key determinant of reproductive cycles in sheep. In Biological Clocks in Seasonal Reproductive Cycles (eds B.K. Follett \& D.E. Follett), pp. 223-236. John Wright \& Sons, Bristol. 
Gross, K.M., MAtsumoto, A.M. \& Bremner, W.J. (1987) Differential control of luteinizing hormone and follicle-stimulating hormone secretion by luteinizing hormone-releasing hormone pulse frequency in man. Journal of Clinical Endocrinology and Metabolism, 64, 675-680.

HaLger, R.L., KARSCh, F.J. \& Foster, D.L. (1977) A new concept for control of the estrous cycle of the ewe based on the temporal relationships between luteinizing hormone, estradiol, and progesterone in peripheral serum and evidence that progesterone inhibits tonic LH secretion. Endocrinology, 101, 807-817.

Hopxins, K.D. \& GLAss. G.V. (1978) Basic Statistics for the Behavioral Sciences. Prentice-Hall Inc., Englewood Clifts, New Jersey.

Huseman, C.A. \& KeLCH. R.P. (1978) Gonadotropin responses and metabolism of synthetic gonadotropinreleasing hormone ( $\mathrm{GnRH}$ ) during constant infusion of $\mathrm{GnRH}$ in men and boys with delayed adolescence. Journal of Clinical Endocrinology and Metabolism, 47, 1325-1331.

ISMAlL, A.A., Niswender, G.D. \& Midgley, JR., A.R. (1972) Radioimmunoassay of testosterone without chromatography. Journal of Clinical Endocrinology and Metabolism, 34, 177-184.

Katt, J.A., DunCan, J.A., Herbon, L., BarKan, A. \& Marshall, J.C. (1985) The frequency of gonadotropinreleasing hormone stimulation determines the number of pituitary gonadotropin-releasing hormone receptors. Endocrinology, 116, 2113-2115.

Kelch, R.P., Clemens, L.E., Markovs, M., Westhoff, M.H. \& Hawkins, D.W. (1975) Metabolism and effects of synthetic gonadotropin-releasing hormone ( $\mathrm{GnRH}$ ) in children and adults. Journal of Clinical Endocrinology and Metabolism, 40, 53-61.

Kelch, R.P., Hopwood, N.J., Sauder, S.E. \& Marshall, J.C. (1985) Evidence for decreasid secretion of gonadotropin-releasing hormone in pubertal boys during short-term testosterone treatment. Pediatric Research, 19, 112-117.

Kelch, R.P., Khoury, S.A., Hal.e, P.M., Hopwood, N.J. \& Marshall, J.C. (1987) Pulsatile secretion of gonadotropins in children. In Episodic Secretion of Hormones (eds W.F. Crowley, Jr. \& J. Hofler), pp. 187-199. John Wiley \& Sons, New York.

MA Tsumoto, A.M. \& BREMNER, W.J. (1984) Modulation of pulsatile gonadotropin secretion by testosterone in man. Journal of Clinical Endocrinology and Metabolism, 58, 609-614.

MCNeiL, L.W., MCKenNa, T.J., LACRoix, A., BenEVEniste, R. \& RABiN, D. (1979) Seventy-two hour infusions of LHRH in normal men: gonadotropin and testicular steroid responses. Journal of Clinical Endocrinology and Metabolism, 49, 149-151.

MidGLEY, JR., A.R. (1966) Radioimmunoassay: a method for human chorionic gonadotropin and human luteinizing hormone. Endocrinology, 79, 10-18.

MidGLEY, JR., A.R. (1967) Radioimmunoassay for human follicle-stimulating hormone. Journal of Clinical Endocrinology and Metabolism, 27, 295-299.

MIDGLEY, JR., A.R. \& JAFFE, R.B. (1971) Regulation of human gonadotropins. X. Episodic fluctuation of LH during the menstrual cycle. Journal of Clinical Endocrinology and Metabolism, 33, 962-969.

Reame, N., Sauder, S.E., Kelch, R.P. \& Marshall, J.C. (1984) Pulsatile gonadotropin secretion during the human menstrual cycle: evidence for altered frequency of gonadotropin-releasing hormone secretion. Journal of Clinical Endocrinology and Metabolism, 59, 328-337.

SANTEN, R.J. \& BARDIN, C.W. (1973) Episodic luteinizing hormone secretion in man. Journal of Clinical Investigation, 52, 2617-2628.

SANTEN, R.J. (1975) Is aromatization of testosterone to estradiol required for inhibition of luteinizing hormone secretion in men. Journal of Clinical Investigation, 56, 1555-1563.

VAlK, T.W., CoRley, K.P., KelCh, R.P. \& Marshall, J.C. (1981) Pulsatile gonadotropin-releasing hormone in gonadotropin deficient and normal men: suppression of follicle-stimulating hormone responses by testosterone. Journal of Clinical Endocrinology and Metabolism, 53, 184-191.

Wildt, L., Hausler, A., Marshall, G., Hutchison, J.S., Plant, T.M., Belchetz, P.E. \& Knobil, E. (1981) Frequency and amplitude of gonadotropin-releasing hormone stimulation and gonadotropin secretion in the Rhesus monkey. Endocrinology, 109, 376-385. 